\section{\#resident's Addòres:}

\section{SEVENTEENTH INTERNATIONAL MEDICAL CONGRESS.}

By SIR THOMAS BARLOW; BART., K.C.V.O.; M.D., F.R.S.,

PHYSICIAN ETTRAORDINARY TO HIS MAJESTY THE KING; CONSULTHNO PHYSICIAN, UNFVERSTT COLLEGE HOSPITAL; PRESIDENT OF THE ROYAL COLLEGE OF PHYSICIANS, LONDON.

Gentlemen,-A whole generation has passed away since the International Medical Congress last met in London.

What a magnificent galaxy of talent in medicine, surgery, and pathology was gathered round the Prince of Wales, who was our Royal Patron at that time!

It is fitting that we should follow the admonition of Ecclesiasticus and praise famous men and the fathers that begat us. Our President, Sir James Paget, was a great clinical pathologist. His mind was stored with all that was then known of the morbid anatomy of surgical disease and injury, and of the family relationships of the different diatheses. He was a splendid teacher and possessed a lucid eloquence and a noral fervour not excelled by any of his contemporaries. Jenner and Gull, Wilks and Gairdner were our great teachers of clinical medicine. Each of them based his knowledge on the sure foundation of the post-mortem room and the hospital wards. We shall not see their like again, for their careers began before the days of specialization, and they were amongst the last of the great general physicians of our time. Hughlings Jackson was the philosophical exponent of the new neurology. Many of lis forecasts were verified by the experiments of David Ferrier, of which I may say there was a remarkable demonstration at the 1881 Congress. Jonathan Hutchinson was the patient accurate recorder of the natural history of disease in multitudinous departments, and characteristically enough he was the organizer of our congress - clinical and pathological museum. The pioneers of abdominal surgery - Spencer Wells, Thomas. Keith, and Lawson Tait-were with us. Huxley, the most brilliaut expositor of natural science of his time, discoursed to us on the relations of medicine and biology. William Bowman, whose work on the minute anatomy of the eye was the foundation of modern English ophthalmology, was one of our most useful members.

Last of all the Englishmen whom I will mention was our great Lister, then in the zenith of his grand career. He has but lately been taken from us in the fullness of years, and we commemorate him to-day in the medal of our Congres's.

Our foreign brethren were not less illustrious in the bede-roll of -medical and surgical achievement. Virchow, the Nestor of morbid anatomy, honoured and beloved by us as by his own countrymen; delivered a fine historical discourse on the value of pathological experiments. Volkmann gave a critical survey of the recent advances of surgery. Robert Koch gave what may truly be called a path-breaking demonstration of the microbial findings in several morbid conditions, and he illustrated their characteristic growth on different organic media. Von Langenbeck and Esmarch - spoke for military surgery; Donders and Snellen for ophthalmology. Baccelli, Murri, and Pantaleoni represented Italian medicine. From the United States came Austin Flint, the accomplished physician and master of physical examination ; Billings, prince of medical bibliographers; and Bigelow the famous surgeon.

The great French school was represented by BrownSéquard and Charcot, Lancereaux and Bouchard and Verneuil and a host of others; but there was one great Frenchman with us who towered aloit amongst all his contemporaries, and who, though not a medical man, exercised by his discoveries a profound influence on the medicine of the world, and that was Louis Pasteur. In his address on vaccination in relation to ohicken cholera and splenic fever, he gracefully linked his most recent researches with the time-honoured labours of Edward Jenner on cow-pox.
Time fails me to speak of other great and honoured names, but surely we may say there were giants in those days.

Now let us realize to ourselves that the Congress of 1881 marked not the parting of the ways, but emphasized the notable fact that the parting of the ways had already been passed. The times of superstition, of empiricism, and of transcendental. speculation had vanished. But what of the period of accurate and detailed observation? That was. neither superseded nor completed, but it was already supplemented and redirected into more fruitful channels by the new development of experimental methods.

If it had not been for the work of Pasteur, Lister, and Koch, which was expounded to us thirty years ago, how poverty-stricken would have been the output of medicine and surgery in this our Congress of 1913 !

The great men-both observers and experimenters-of whom I have spoken were like mountain peaks towering above the plain of ordinary medical humanity, and wo sometimes sadly ask where are the mountain peaks now? That is a shallow and unenlightened question. For in, deed, thanks to the unremitting labours of workers in multitudinous paths, we have attained a glorious heritage -not of high mountain peaks and deep valleys-but a lofty and magnificent tableland of well ordered and correlated knowledge.

Consider the bare fact that the fifteen sections of tho 1881 Congress have, by the inevitable specialization and concentration of work, become twenty-three sections and three subsections in 1913 , but so imperative is the demand for mutual conference that we have no less than fourtecn meetings arranged in which sections have found it desirable to discuss various problems in joint session.

In what ways have we pursued and expanded the work of our fathers? First, unquestionably, in the development and application of bacteriology. Koch's great discovery of the life-history of the tubercle bacillus was published in tho year after the London Congress, and what an enormous body of knowledge has grown out of that discovery! We are learning to discriminate between the essential and causal factors of disease and the concomitants, such as combined and terminal infections. The by-products and the antibodies developed to neutralize bacterial life, of which we see the beneficent rôle in Nature's own cure of an acute specifis disease, have been made to yield their share in two important methods of treatment-namely, sero-therapy and vaccine-therapy.

We have also faced the problem of strengthening the phagocytosis of the patient. I need not dwell on the history of the Klebs-Loeffler bacillus and the causation of diphtheria, nor on the indubitable efficacy of the most important of all the antitoxins, nor on the singular parallelism between the bacteriological findings in atypical throat exudations with the ambiguous symptomatology which clinical observation reveals. Nor need I dwell on the extension of bacteriological investigation of typhoid fertr which has been fruitful in new measures of prophylaxis and defence of the community.

We have learnt something about the natural history of the ultra-minute organisms which as "filter passers" elude our microscopic investigation.

There are still great gaps in our knowledge of the bacteriology of the acute specific diseases, but it is a gain to have learnt from the study of recent epidemics that infantile paralysis must be grouped with the infective diseases, and, thanks to Flexner, we know many of the reactions of its elusive organism.

Great advances have been made in protozoology, in helminthology, and indeed in the whole subject of the relation of parasites to the diseases of $m a n$ and animals. In tropical diseases these studies, as well as bacteriology, have brought about a rich harrest. Malta fever, plague, malaria, sleeping sickness, have all yielded more or less of their secrets. Sometimes the whole cycle of the disease has been discovered, rationalized in every respect, and its successful treatment has been evolved.

In other cases, as in malaria, sleeping sickness, and yellow fever, where only parts of the natural history of the disease have been elucidated, nevertheless enough real knowledge has been acquired to enable important, though sometimes costly, hygienic measures to be successfully employed. Here it is fitting that we should offer our homage to our American brethren for their splendid 
hygienic work in Cuba, in Panama, in the Philippines, and in Costa Rica, and for the efforts which they are organizing for a world-wide crusade against ankylostoma disease.

Chemical pathology has widened our knowledge and our resources, and the mystery of immunity has been to some extent illuminated.

The detailed examination of the morphological elements and the chemical characters of the blood and of other body fluids has eventuated in the revriting of some of our physiology, and the pathological extension of the knowledge thus gained has improved the diagnosis and the treatment of several diseases. Thirty years ago Ord demonstrated to the Congress of that time examples of the disease which he had defined as myxoedema, but which, with surer instinct, Gull had described as a cretinoid state in adults. The gradual evolution of the doctrine of thyroid insufficiency and of its therapeutics is a model of induction; and this important discovery has given a great impetus to the whole study of internal secretions, as well as to the employment of organic extracts, of which the last and most interesting is that of the pituitary body.

The empirical and then the experimental study of small variations in the ordinary diets of adults and children and infants in different social strata and in different countries has been fruitful in many unexpected ways. The great milk problem is still with us, but we have learnt the blunders of our early generalizations. Cleanliness in the milk supply from start to finish has a far more exhaustive meaning than in days gone by. The curious disease beri-beri, which some of us have long thought had parallelisms with scurvy, has been shown, at all events amongst rice-eating people, to depend on the loss of the nutritive material just internal to the pericarp, which the ordinary process of milling removes.

The patient study of chronic alcoholism has opened up a new chapter in nervous diseases. The routine traditional employment of alcohol in disease has happily been largely discredited. The open-air treatment of all forms of tuberculous lesions has had a wide indirect influence not only on the treatment of other chronic ailments, but on the daily life of the people.

The recognition and radical treatment of oral sepsis due to damage to the gums in consequence of various disorders of the teeth has been followed by remarkable benefit. A strong case has been made out for intestinal stasis as a cause of various forms of malnutrition and for operative measures in dealing with slight mechanical obstructions ; on this subject we hope for further evidence.

The additions to diagnosis yielded by $x$-ray exploration are like the creation of a sixth sense, and its curative applications and those of radium are the opening of a new chapter of therapeutics.

I ventured to hint that medicine had now and then led to the rewriting of some chapters of physiology, and I may add that recent researches on diseases of the heart have led to the re-editing of neglected knowledge of the minute structure of heart muscle, and of orderly and disorderly mechanism of its movements.

Of the magnificent triumphs of the surgery of this generation it is beyond my potwer adequately to speak, but I can refer to the wide fields opened up through the beneficent protection of Listerism. We are staggered by the reasoned and calculated audacity of our brethren when sinuses of the skull are drained, cerebral abscesses evacuated, cercbral tumours removed, the pituitary body even being investigated, when pleuro-pericardial adhesions are freed, to the great relief of the heart, when different parts of the alimentary canal are short-circuited and when one or other damaged viscus is removed either entirely or in part. The active co-operation of surgeons and physicians has gained for us some knowledge of what Moynihan and others have happily described as "living pathology," and we gratefully acknowledge the invaluable information of correlated symptoms, signs, and morbid conditions, and the statistics of comparative frequency which surgical experience has brought to the common store.

The supreme gain, after all, is that many more useful lives are saved than in the last generation, that the realm of grave and hitherto incurable disease is invaded on every side, and that the danger of operation qua operation is retreating to a vanishing point.

It is impossible even to enumerate the varied ways in which medicine has co-operated with economics, social legislation and philanthropy, which we sum up briefly as public health. The school house and the scholars, the home of the poor, the colliery, and the factory, tho dangerous occupations, the sunless life of the mentally deficient, have benefited, and will benefit still more, by its friendly invasion. And I venture to foretell that, not many year's hence, every department of life and work shall be strengthened and purified and brightened by its genial and penetrating influence.

Surely I have said more than enough to justify my contention that we have come into a goodly heritage and that that heritage is like a lofty and magnificent tableland of knowledge and efficiency. The gaps are being filled; we are no longer isolated, but are working side by side on adjacent areas which are inseparably connected. Every day we gain fresh help from the auxiliary sciences, and we realize more and more the unity and the universality of medicine.

Brethren from foreign lands, we thank you for the treasures, new and old, of observation and experiment, and of a ripe experience, which you have brought to this Congress for the common weal.

I venture to affirm that the output of work of the Congress week in its twenty-three goodly volumes will astonish civilized countries by its amount and its solid worth.

I welcome you to our dear country, this ancient home of freedom, and I speak not only for the medical men of the British Isles but for our brethren of the Overseas Dominions, who join with us in our cordial greeting.

May this Congress add to the common store of fruitful and useful knowledge; may it increase our good fellowship, our mutual understanding and co-operation, and may it help to break down the barriers of race and country in the onward beneficent march of world medicine.

\section{Addrtes: in ffledirime,}

\section{MEDICAL PROGNOSIS : ITS METHODS, ITS EVOLUTION, ITS LIMITATIONS.}

Delivered at the Seventeenth International Congress of Medicine.

By A. CHAUFFARD, M.D.,

PROFESSOR OF CLINICAL MEDICINE IN THE UNIVERSITY OF PARIS ; MEMBER OF THE ACADEMY OF MEDICINE.

Mr. President, Ladies, and Gentlemen,-In asking me to address to-day this great medical assembly, the Committee of the Serenteenth International Congress of Medicine has conferred on me a signal honour for which I desire in the first place to express my very sincere thanks. I should feel most unworthy of this high distinction were I not conscious that it is offered much less to my person than to French medical science. The medical men of France have come in large numbers to this Congress with the desire of learning, of making known their work, and also of maintaining and tightening the bonds of amity and esteem which link them to their colleagues of every nation, and more especially of the great country which is receiving them so splendidly today. Since, for one brief instant, it is given to me to be their spokesman before you, allow me to enter immediately upon the theme which I shall have the honour to consider in this address.

\section{Evolution.}

The subject I purpose to discuss is that of medical prognosis considered in regard to its methods, its evolution, its limitations.

Medical prognosis! Is it not for us the daily problem, the anxious question which is constantly being put to us and which we put to ourselves? Ever since there have been sick patients and men who endeavour to relieve them and to restore them to health, the same query has come up in every case: Will a cure be effected, and by what therapeutical means? Prognosis and treatment-such were from the very first the two instinctive needs, the two immediate demands of the sick man. It was only at 